\title{
Energy value of meat in selected species of feathered game
}

\author{
František Vitula ${ }^{1}$, Pavel Suchý ${ }^{2}$, Eva Straková ${ }^{2}$ Kateřina Karásková², David Zapletal², \\ Leo Kroupa ${ }^{2}$
}

${ }^{1}$ Department of Veterinary Ecology and Environmental Protection, Faculty of Veterinary Hygiene and Ecology, University of Veterinary and Pharmaceutical Sciences Brno

${ }^{2}$ Department of Nutrition, Animal Husbandry and Animal Hygiene, Faculty of Veterinary Hygiene and Ecology, University of Veterinary and Pharmaceutical Sciences Brno

Received March 18, 2010

Accepted September 21, 2010

\begin{abstract}
The aim of this work was to compare gross energy (GE) in breast and thigh muscles in the following six species of feathered game reared in Europe: guineafowl (Numida meleagris), common pheasant (Phasianus colchicus), Japanese quail (Coturnix coturnix japonica), chukar (Alectoris chucar), grey partridge (Perdix perdix) and wild turkey (Meleagris gallopavo). Calorimetric analysis revealed significant $(P \leq 0.05)$ and highly significant $(P \leq 0.01)$ differences between individual species in the content of energy in breast and thigh muscles. The highest content of energy (recalculated to dry matter) was found in breast muscles from wild turkey (24.75 MJ.kg-1) and Japanese quail $\left(24.57 \mathrm{MJ}^{-1} \mathrm{~kg}^{-1}\right)$ whereas the highest content of energy (recalculated to dry matter) in thigh muscles was found in Japanese quail and grey partridge. Highly significant $(P \leq 0.01)$ differences in the energy content were also found between breast and thigh muscles in all studied game species except for wild turkey. Differences in the content of energy in muscles between individual species occur mainly due to different contents of fat in muscles. This is also confirmed by high correlation coefficients between the content of energy and the content of fat in breast $(r=0.912)$ and thigh muscles $(r=0.878)$. Our study provides more specific data on the amount of energy in muscles of major species of feathered game reared in Europe and significantly extends current knowledge in this field.
\end{abstract}

Game birds, breast and thigh muscles, the content of energy, crude protein and fat

The content of energy, i.e. gross energy (GE), is one of the most important criteria in evaluation of the dietetic value of food. Scientific literature provides only sporadic references to GE of meat and relevant data for most species of feathered game are still not available. Valuable information can be obtained from the USDA National Nutrient Database for Standard Reference (U.S. Department of Agriculture, Agricultural Research Service 2009). This database contains energy values for some of the feathered game species such as common pheasant (breast muscles - $133 \mathrm{kcal}$ per $100 \mathrm{~g}$ of muscles $\left(5.5 \mathrm{MJ} \cdot \mathrm{kg}^{-1}\right)$, thigh muscles - $134 \mathrm{kcal}$ per $100 \mathrm{~g}$ of muscles $\left(5.5 \mathrm{MJ} \cdot \mathrm{kg}^{-1}\right)$, quail (breast muscles - 123 kcal per $100 \mathrm{~g}$ of muscles $\left(5.1 \mathrm{MJ} \cdot \mathrm{kg}^{-1}\right)$, thigh muscles $-134 \mathrm{kcal} / 100 \mathrm{~g}$ of muscles $(5.6$ $\mathrm{MJ} \cdot \mathrm{kg}^{-1}$ ) and guineafowl (raw meat - $110 \mathrm{kcal}$ per $100 \mathrm{~g}$ of meat $\left(4.6 \mathrm{MJ} \cdot \mathrm{kg}^{-1}\right.$ ), raw meat and skin $-158 \mathrm{kcal} / 100 \mathrm{~g}\left(6.6 \mathrm{MJ} \cdot \mathrm{kg}^{-1}\right)$. The total amount of energy in meat depends on the content of water and the amount and mutual ratios of organic components such as proteins and fat. As a result, thigh muscles that contain more fat and less proteins have also a higher value of energy compared to breast muscles. This was reported in broiler chickens by Suchý et al. (2002) and in pheasants by Večerek et al. (2005). The chemical composition of meat in pheasants was studied by Petkov (1984) who showed a higher nutritional value in breast muscles compared to thigh muscles. Kuzniacka et al. (2007) reported that the contents of protein and fat in the meat of pheasants aged 16 and 20 weeks varied in a range of $24.53-25.19 \%$, and $2.31-2.78 \%$, respectively. According to a study by Gaglianone et al. (2006), the contents of proteins and fat in the muscles of partridges ranged between 25.2

Address for correspondence:

Ing. František Vitula, Ph.D.

University of Veterinary and Pharmaceutical Science Brno

Faculty of Veterinary Hygiene and Ecology.

Department of Veterinary Ecology and Environment Protection

Palackého 1/3 61242 Brno, Czech Republic

Phone: +420541562663

Fax: +420 541562675

E-mail: vitulaf@vfu.cz

http://www.vfu.cz/acta-vet/actavet.htm 
and $29.1 \%$, or between 1.6 and 5.6\%, respectively. Cerioli et al. (1992) pointed out that guineafowl with low fat content in breast and thigh muscles represents high-quality meat.

\section{Materials and Methods}

The aim of this work was to determine the content of energy in breast and thigh muscles in the following six species of feathered game: wild turkey (Meleagris gallopavo), guineafowl (Numida meleagris), chukar (Alectoris chucar), Japanese quail (Coturnix coturnix japonica), common pheasant (Phasianus colchicus) and grey partridge (Perdix perdix). The measured values were compared with the energy values in the muscles of broiler chickens (unpublished results from the analyses conducted at the Department of Nutrition, Husbandry and Animal Hygiene). Game species were obtained from a farm of feathered game owned by the University of Veterinary and Pharmaceutical Sciences Brno. Analyses were performed with 1-year-old animals; the live weight of animals corresponded to that of animals used for hunting purposes (10 individuals from each species). After stunning, the animals were allowed to bleed. Samples of breast and thigh muscles were collected for laboratory processing (each sample was analyzed twice and the average value was subsequently used). Muscles were thoroughly homogenized prior to analysis. Pre-dry matter and dry matter were determined by drying a sample at $105^{\circ} \mathrm{C}$ to constant weight. The energy value was determined as the heat of combustion of the sample using the calorimetric instrument AC 500 (LECO). Additional indicators such as the content of nitrogen according to Kjeldahl (multiplied with a coefficient of 6.25, using the Büchi analyser (Centec automatika, spol. s.r.o.)) and the content of fat (using petrolether extraction and ANKOM ${ }^{\text {XT10 }}$ Fat Analyzer (O.K. SERVIS BioPro)) were determined. The results of energy values are expressed relative to the original weight and dry matter.

The results obtained were processed using mathematical and statistical methods using the statistical programme Unistat version 5.6 for Excel. Mean values and their differences were evaluated using a multiple comparison using the Tukey-HSD test, at two levels of significance: $P \leq 0.01$ and $P \leq 0.05$. Each indicator is presented by the mean value $(\mathrm{x})$ and standard deviation $( \pm \mathrm{SD})$. The Pearson correlation was used to determine relationship between the two indicators. The significance of mean values was evaluated between all investigated species of feathered game being expressed using symbols ${ }^{\mathrm{a}: \mathrm{b}}(P \leq 0.05)^{\mathrm{A}: \mathrm{B}}(P \leq 0.01)$. Furthermore, the significance of a monitored indicator in each species of feathered game was assessed between breast and thigh muscles, being marked with symbols * $(P \leq 0.05) * *(P \leq 0.01)$, NS non-significant.

\section{Results}

The results of energy values in muscles of feathered game are recalculated to the original (fresh) matter (Table 2) and to dry matter (Table 3). The dry matter of muscles in individual species of feathered game is provided in Table 1 . The content of dry matter represents a rough value since it is associated with a great error caused by the evaporation of water, particularly during the time-dependent processing of samples, the timing of the collection of muscle tissue, homogenization of a sample, weighing, etc. This is also confirmed by the results where no significant differences were found between individual species in mean values for breast muscles. The preparation of samples from thigh muscle tissue is timeconsuming (the removal of skin, subcutaneous fat, bones from thighs), particularly in smallsize game species and is associated with loss of water due to uncontrolled evaporation. This fact is documented by the results presented in Table 1. As a result, the statistical processing showed highly significant differences in the dry matter of thigh muscles in Japanese quail

Table 1. The content of dry matter in muscles from individual species of feathered game in $\mathrm{g} \cdot \mathrm{kg}^{-1}(\mathrm{x} \pm \mathrm{SD})$

\begin{tabular}{lllc}
\hline Dry matter of muscles & Breast muscles & Thigh muscles & Breast - Thigh muscles \\
\hline Wild turkey & $276.31 \pm 37.02$ & $275.45 \pm 24.06^{\mathrm{A}}$ & $\mathrm{NS}$ \\
Guineafowl & $272.84 \pm 5.65$ & $267.25 \pm 13.07^{\mathrm{C}}$ & $\mathrm{NS}$ \\
Chukar & $271.93 \pm 10.68$ & $274.75 \pm 18.03^{\mathrm{E}}$ & $\mathrm{NS}$ \\
Japanese quail & $287.83 \pm 12.49$ & $357.12 \pm 48.28^{\mathrm{B}, \mathrm{D}, \mathrm{F}, \mathrm{G}}$ & $* *$ \\
Common pheasant & $285.57 \pm 9.95$ & $280.90 \pm 10.33^{\mathrm{H}, \mathrm{Ch}}$ & $\mathrm{NS}$ \\
Grey partridge & $282.84 \pm 11.61$ & $321.93 \pm 30.03^{\mathrm{B}, \mathrm{D}, \mathrm{F}, \mathrm{i}}$ & $* *$ \\
\hline
\end{tabular}

** - significant difference $(P \leq 0.01)$, NS - non-significant difference, $\mathrm{AB}, \mathrm{CD}, \mathrm{EF}, \mathrm{GH}, \mathrm{CHI}=P \leq 0.01$, $\mathrm{Ab}, \mathrm{Cd}, \mathrm{Ef}, \mathrm{Gh}, \mathrm{CHi} \quad=P \leq 0.05$ 
and grey partridge compared to other species, also revealing differences between breast and thigh muscles. There is a lack of exact data on the chemical composition of muscles from feathered game in scientific literature.

The values of energy in breast and thigh muscles in feathered game related to the original mass are listed in Table 2. It follows from the table that the highest content of energy $\left(7.09 \mathrm{MJ} \cdot \mathrm{kg}^{-1}\right)$ is in breast muscles from Japanese quail, which differs highly significantly $(P \leq 0.01)$ from the lowest energy value $\left(6.15 \mathrm{MJ} \cdot \mathrm{kg}^{-1}\right)$ found in guineafowl. Significantly higher differences in the energy value between individual kinds of muscles from game species were found in thigh muscles. The highest energy value $\left(9.75 \mathrm{MJ} \cdot \mathrm{kg}^{-1}\right)$ was found in thigh muscles in Japanese quail, which differed highly significantly $(P \leq 0.01)$ from most mean values in the species under study (Table 2$)$. The lowest energy value $\left(6.46 \mathrm{MJ} \cdot \mathrm{kg}^{-1}\right)$ in thigh muscles was determined in guineafowl.

Table 2. Mean values of energy content in muscles from individual species in $\mathrm{MJ}^{\mathrm{kg}} \mathrm{kg}^{-1}(\mathrm{x} \pm \mathrm{SD})$

\begin{tabular}{|c|c|c|c|}
\hline GE (original mass) & Breast muscles & Thigh muscles & Breast - Thigh muscles \\
\hline Wild turkey & $6.89 \pm 1.39$ & $7.10 \pm 0.89^{\mathrm{A}}$ & NS \\
\hline Guineafowl & $6.15 \pm 0.18^{\mathrm{A}}$ & $6.46 \pm 0.51^{\mathrm{C}}$ & NS \\
\hline Chukar & $6.26 \pm 0.35$ & $6.67 \pm 0.66^{\mathrm{E}}$ & NS \\
\hline Japanese quail & $7.09 \pm 0.48^{\mathrm{B}}$ & $9.75 \pm 1.79^{\mathrm{B}, \mathrm{D}, \mathrm{F}, \mathrm{G}}$ & $* *$ \\
\hline Common pheasant & $6.60 \pm 0.29$ & $7.11 \pm 0.42^{\mathrm{H}, \mathrm{Ch}}$ & $* *$ \\
\hline Grey partridge & $6.66 \pm 0.46$ & $8.60^{i} \pm 1.02^{\mathrm{b}, \mathrm{D}, \mathrm{F}, \mathrm{i}}$ & $* *$ \\
\hline
\end{tabular}

** - significant difference $(P \leq 0.01)$, NS - non-significant difference, $\mathrm{AB}, \mathrm{CD}, \mathrm{EF}, \mathrm{GH}, \mathrm{CHI}=P \leq 0.01$, $\mathrm{Ab}, \mathrm{Cd}, \mathrm{Ef}, \mathrm{Gh}, \mathrm{CHi} \quad=P \leq 0.05$

Energy values in muscles recalculated to original mass can only be considered as rough values since they are affected by the content of water in muscles and can therefore be influenced by water evaporation during the processing of samples for energy value analysis (as mentioned above) and also during storage or cooking of game meat in practical conditions. The energy values determined in this study are higher compared to those reported in the USDA National Nutrient Database for Standard Reference (2009) that were calculated from the chemical composition of muscles compared to our values that were determined as the heat of combustion of a sample using a calorimetric instrument and therefore present the real content of energy.

The most precise and most characteristic expression of energy is when it is related to dry matter of muscles. Such value characterizes the energy content in a sample from muscles

Table 3. Mean values of energy in dry matter of muscles from individual species of feathered game in $\mathrm{MJ} \cdot \mathrm{kg}^{-1}$ $(\mathrm{x} \pm \mathrm{SD})$

\begin{tabular}{|c|c|c|c|}
\hline BE (dry matter) & Breast muscles & Thigh muscles & Breast - Thigh muscles \\
\hline Wild turkey & $24.75 \pm 1.62^{\mathrm{A}}$ & $25.73 \pm 1.08^{\mathrm{A}}$ & NS \\
\hline Guineafowl & $22.55 \pm 0.22^{\mathrm{B}, \mathrm{C}}$ & $24.16 \pm 0.80^{\mathrm{b}, \mathrm{C}}$ & $* *$ \\
\hline Chukar & $23.03 \pm 0.57^{\mathrm{B}, \mathrm{E}}$ & $24.22 \pm 0.85^{\mathrm{b}, \mathrm{E}}$ & $* *$ \\
\hline Japanese quail & $24.57 \pm 0.76^{\mathrm{D}, \mathrm{F}, \mathrm{G}}$ & $27.15 \pm 1.61^{\mathrm{b}, \mathrm{D}, \mathrm{F}, \mathrm{G}}$ & $* *$ \\
\hline Common pheasant & $23.13 \pm 0.48^{\mathrm{B}, \mathrm{H}}$ & $25.29 \pm 0.62^{\mathrm{H}, \mathrm{Ch}}$ & $* *$ \\
\hline Grey partridge & $23.54 \pm 0.71^{\mathrm{b}}$ & $26.69 \pm 0.68^{\mathrm{D}, \mathrm{F}, \mathrm{i}, \mathrm{J}}$ & $* *$ \\
\hline Broiler chickens* & $23.77 \pm 0.45^{\mathrm{d}}$ & $27.31 \pm 0.81^{\mathrm{B}, \mathrm{D}, \mathrm{F}, \mathrm{I}}$ & $* *$ \\
\hline
\end{tabular}

* unpublished results from the analyses conducted in the Department of Nutrition, Husbandry and Animal Hygiene

** - significant difference $(P \leq 0.01)$, NS - non-significant difference, $\mathrm{AB}, \mathrm{CD}, \mathrm{EF}, \mathrm{GH}, \mathrm{CHI}=P \leq 0.01$, $\mathrm{Ab}, \mathrm{Cd}, \mathrm{Ef}, \mathrm{Gh}, \mathrm{CHi} \quad=P \leq 0.05$ 
and does not suffer from errors associated with the collection and processing of a sample. It follows from Table 3 that there are highly significant differences between individual species of feathered game $(P \leq 0.01)$, or significant $(P \leq 0.05)$ differences in the content of energy in dry matter in both breast and thigh muscles. Table 3 also shows the results of the analysis of meat from broiler chickens for comparison.

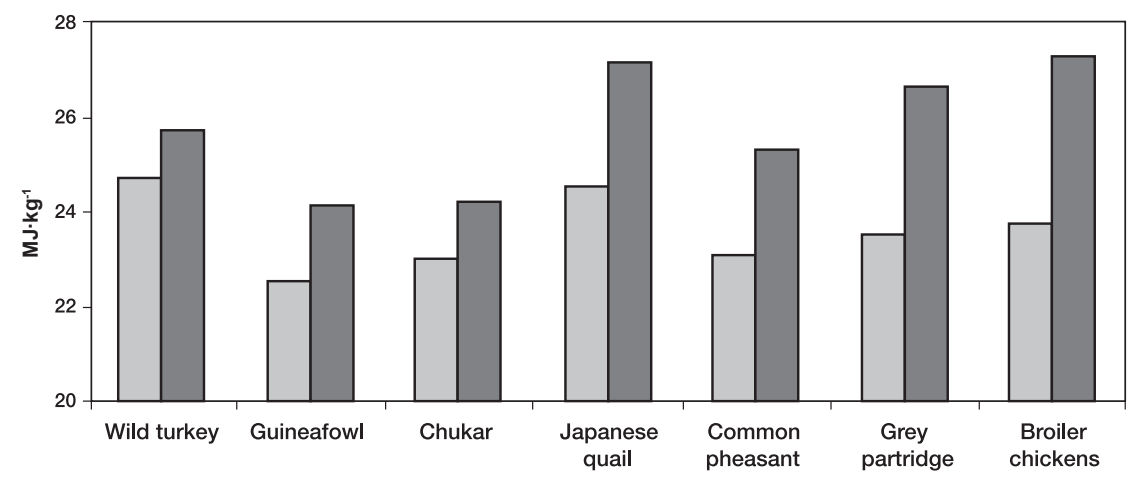

$\square$ Breast $\mathrm{m}$. $\square$ Thigh $\mathrm{m}$.

Fig. 1. Differences in the content of energy in dry matter of breast and thigh muscles from feathered game species in $\mathrm{MJ} \cdot \mathrm{kg}^{-1}(\mathrm{x})$.

It follows from the results that the amount of energy in dry matter of thigh muscles in all species except for wild turkey is significantly higher $(P \leq 0.01)$ compared to breast muscles. The highest content of energy in breast and thigh muscles $\left(24.57 \mathrm{MJ} \cdot \mathrm{kg}^{-1}\right.$ and $\left.27.15 \mathrm{MJ} \cdot \mathrm{kg}^{-1}\right)$ was found in Japanese quail whereas the lowest contents $\left(22.55 \mathrm{MJ} \cdot \mathrm{kg}^{-1}\right.$ and $24.16 \mathrm{MJ} \cdot \mathrm{kg}^{-1}$ ) were found in guineafowl (Fig. 1).

From a dietetic point of view, the most favourable amounts of energy (Table 3), fat (Table 4) and proteins (Table 5) of all monitored species of feathered game were found in guineafowl and chukar. Similar findings were also reported by Cerioli et al. (1992) who emphasised the high dietetic quality of muscles from guineafowl, particularly for a low fat content in breast and thigh muscles. The content of energy in muscles is influenced by the chemical composition, particularly by the content of lipids in muscles whose mean values are listed in Table 4. It follows from the table that there are highly significant $(P \leq 0.01)$ and significant $(P \leq 0.05)$ inter-species differences in the content of fat in muscles but also highly significant differences $(P \leq 0.01)$ between breast and thigh muscles. The highest mean value of fat was $130.64 \mathrm{~g} \cdot \mathrm{kg}^{-1}$ in breast muscles and $299.60 \mathrm{~g} \cdot \mathrm{kg}^{-1}$ in thigh muscles in Japanese quail, which also implied high energy value of muscles.

Table 4. Mean crude fat content in the dry matter of muscles from individual species of feathered game in $\mathrm{g} \cdot \mathrm{kg}^{-1}$ $(\mathrm{x} \pm \mathrm{SD})$

\begin{tabular}{lccc}
\hline Crude fat & Breast muscles & Thigh muscles & Breast - Thigh muscles \\
\hline Wild turkey & $151.44 \pm 111.19^{\mathrm{A}}$ & $235.37 \pm 76.48^{\mathrm{A}}$ & NS \\
Guineafowl & $22.89 \pm 9.96^{\mathrm{B}, \mathrm{C}}$ & $147.93 \pm 41.55^{\mathrm{b}, \mathrm{C}}$ & $* *$ \\
Chukar & $40.64 \pm 24.68^{\mathrm{B}, \mathrm{E}}$ & $161.40 \pm 86.98^{\mathrm{E}}$ & $* *$ \\
Japanese quail & $130.64 \pm 50.41^{\mathrm{D}, \mathrm{F}, \mathrm{G}}$ & $299.60 \pm 69.46^{\mathrm{D}, \mathrm{F}, \mathrm{G}}$ & $* *$ \\
Common pheasant & $46.59 \pm 22.15^{\mathrm{B}, \mathrm{h}}$ & $208.32 \pm 35.75^{\mathrm{h}, \mathrm{Ch}}$ & $* *$ \\
Grey partridge & $75.72 \pm 50.08^{\mathrm{b}}$ & $291.62 \pm 48.92^{\mathrm{D}, \mathrm{F}, \mathrm{i}}$ & $* *$ \\
\hline
\end{tabular}

** - significant difference $(P \leq 0.01)$, NS - non-significant difference, $\mathrm{AB}, \mathrm{CD}, \mathrm{EF}, \mathrm{GH}, \mathrm{CHI}=P \leq 0.01$, $\mathrm{Ab}, \mathrm{Cd}, \mathrm{Ef}, \mathrm{Gh}, \mathrm{CHi}=P \leq 0.05$ 
Muscles from feathered game were also analysed for the content of crude protein whose mean values in individual species are listed in Table 5. It follows from the results that breast muscles contain a highly significant level $(P \leq 0.01)$ of crude protein compared to thigh muscles.

Table 5. Mean crude protein content in the dry matter of muscles from individual species of feathered game in $\mathrm{g}^{\mathrm{kg}} \mathrm{kg}^{-1}(\mathrm{x} \pm \mathrm{SD})$

\begin{tabular}{llcc}
\hline Crude protein & Breast muscles & Thigh muscles & Breast - Thigh muscles \\
\hline Wild turkey & $819.07 \pm 111.16^{\mathrm{A}}$ & $715.30 \pm 77.00^{\mathrm{A}}$ & $*$ \\
Guineafowl & $885.55 \pm 20.70$ & $748.92 \pm 42.22^{\mathrm{C}}$ & $* *$ \\
Chukar & $924.37 \pm 31.11^{\mathrm{B}, \mathrm{C}}$ & $811.96 \pm 53.55^{\mathrm{B}, \mathrm{E}}$ & $* *$ \\
Japanese quail & $814.80 \pm 47.98^{\mathrm{D}, \mathrm{E}}$ & $667.24 \pm 62.95^{\mathrm{d}, \mathrm{F}, \mathrm{G}}$ & $* *$ \\
Common pheasant & $906.68 \pm 32.47^{\mathrm{b}, \mathrm{F}}$ & $748.44 \pm 41.24^{\mathrm{d}, \mathrm{h}}$ & $* *$ \\
Grey partridge & $876.78 \pm 54.67$ & $674.17 \pm 51.08^{\mathrm{D}, \mathrm{F}}$ & \\
\hline
\end{tabular}

** - significant difference $(P \leq 0.01)$, NS - non-significant difference, $\mathrm{AB}, \mathrm{CD}, \mathrm{EF}, \mathrm{GH}, \mathrm{CHI}=P \leq 0.01$, $\mathrm{Ab}, \mathrm{Cd}, \mathrm{Ef}, \mathrm{Gh}, \mathrm{CHi}=P \leq 0.05$

\section{Discussion}

Differences in chemical composition of breast and thigh muscles are in agreement with the conclusions published for broiler chickens by Suchý et al. (2002) and for pheasants by Večerek et al. (2005). Our results also correspond to the data reported in pheasants by Kuzniacka et al. (2007) and in partridges by Gaglianone et al. (2006). On the basis of our values of energy found in muscles, it can be concluded that the differences in the content of energy in muscles are significantly influenced by the presence of muscular fat rather than by crude protein. This conclusion is supported by correlation analysis which confirmed a highly positive correlation between the amount of muscular fat and the energy value of muscles. Correlation coefficients for breast muscles and thigh muscles $(\mathrm{r}=0.912$ and $\mathrm{r}=0.878)$ were calculated using the Pearson correlation. A negative correlation was found between the energy value of dry matter of muscles and crude protein, being characterized by the following correlation coefficients: $r=-0.802$ for breast muscles, $r=-0.781$ for thigh muscles. This also implies a highly negative correlation between muscular fat and crude protein characterized in breast muscles by $\mathrm{r}=-0.906$, and in thigh muscles by $r=-0.896$. It follows from the results that there are significant differences in energy value of meat of feathered game. Such differences particularly occur due to the different chemical composition of muscles of individual species of feathered game. The energy value of muscles depends on the content of fat in muscles. Our results have confirmed that there is a highly significant difference between breast and thigh muscles. Such differences are caused by different contents of fat and crude protein in individual kinds of muscles. Breast muscles are characterized by a high content of crude proteins and a low content of fat which implies a lower energy value compared to thigh muscles. In terms of energy, the results of our study have proven that there is a highly positive correlation between the content of fat and the energy value of muscles and a highly negative correlation between the content of crude protein and the energy value of muscles. In terms of nutrition, the meat from feathered game can be considered as a dietetically valuable food, having a higher nutritional value compared to chicken meat. Meat from guineafowl and chukar can be evaluated very positively among all individual species of feathered game investigated in our study, particularly for the high content of protein, the low content of fat, and thus for the low content of energy.

\section{Energetická hodnota masa vybraných druhů pernaté zvěře}

Cílem práce bylo porovnat obsah brutto energie $(\mathrm{BE}) \mathrm{v}$ prsní a stehenní svalovině u šesti druhů pernaté zvěře chované v evropských podmínkách: perličky kropenaté 
(Numida meleagris), bažanta obecného (Phasianus colchicus), japonské křepelky (Coturnix coturnix japonica), orebice čukar (Alectoris chucar), koroptve polní (Perdix perdix) a krocana divokého (Meleagris gallopavo). Na základě kalorimetrického stanovení bylo zjištěno, že mezi jednotlivými druhy zvěre existují významné $(P \leq 0.05)$, až vysoce významné $(P \leq 0.01)$ rozdíly v energetickém obsahu prsní i stehenní svaloviny. Nejvyšší obsah energie v sušině prsní svaloviny $24.75 \mathrm{MJ} \cdot \mathrm{kg}^{-1}$ a $24.57 \mathrm{MJ} \cdot \mathrm{kg}^{-1}$ byl prokázán u krocana divokého a japonské křepelky. Nejvyšší obsah energie v sušině stehenní svaloviny byl prokázán u japonské křepelky a koroptve polní. Vysoce významný $(P \leq 0.01)$ rozdíl u sledovaných druhů zvěre, vyjma krocana divokého v obsahu energie, byl prokázán i mezi prsní a stehenní svalovinou. Rozdíly v obsahu energie svaloviny mezi jednotlivými druhy je dán především rozdílným obsahem svalového tuku. Tuto skutečnost potvrzují i stanovené vysoké korelační koeficienty mezi obsahem energie a obsahem tuku v prsní $(r=0.912)$ i stehenní svalovině $(\mathrm{r}=0.878)$.

\section{Acknowledgements}

This study was funded from the Grant Project of the Ministry of Agriculture of the Czech Republic NAZV No. QH 91276.

\section{References}

Cerioli C, Fiorentini L, Piva G 1992: Nutritive value of meat of guineafowls (Numida meleagris). Riv Sci Aliment 21: 373-382

Gaglianone ME, Ariki J, De Souza PA, De Souza HBA, De Moraes VMB, Vargas FC 2006:

Carcass income and chemical composition of the native partridge (Rhynchotus rufescens - Tinamiformes) meat. Cienc rural 36: 258-262

Kuzniacka J, Adamski M, Bernacki Z 2007: Effect of age and sex of pheasants (Phasianus colchicus L.) on selected physical properties and chemical composition of meat. Ann Anim Sci 7: 45-53

Petkov R 1984: Chemical composition of pheasant meat. Vet Med Nauki 21: 106-110

Suchý P, Jelínek P, Straková E, Hucl J 2002: Chemical composition of muscles of hybrid broiler chickens during prolonged feeding. Czech J Anim Sci 47: 511-518

U.S. Department of Agriculture, Agricultural Research Service. USDA National Nutrient Database for Standard Reference, Release 22. Nutrient Data Laboratory Home Page. Available at: http://www.ars.usda.gov/nutrientdata. Accessed March 1, 2010

Večerek V, Suchý P, Straková E, Vitula F, Mikundová M 2005: Variation in the chemical composition of muscles in young pheasants during their growth. Arch Tierzucht 48: 290-298 